\title{
COLLABORATION BETWEEN CHILDREN, FAMILY AND TEACHERS, IN PROMOTING CHILD'S LEARNING SKILLS
}

\author{
Asja Vanaga \\ University of Latvia
}

\begin{abstract}
Partnership between teacher and parents forms understanding about mutual communication and the benefits for learning process out of that. Teacher's observations points to a different understanding on the collaboration with children as a successive process in setting and achieving learning goals. The aim of the article is to reveal how to turn the initiative to involve in preschool learning process expressed by family, into planned engagement in learning process. Daily activities planned by teacher turns parents into educators and involves whole family into initiative fostering project, which strengthens overall partnership between teacher, child and family.
\end{abstract}

Keywords: family, partnership, engagement in learning process, involvement in learning process, learning, self-directed learning.

\section{Introduction}

Partnership between family, school and community has a large and positive impact on learning outcomes, regardless the age of our children. In most cases, parents are willing to participate in learning process, but the lack of information and experience leads to frequent misunderstandings and wrong interpretation of processes in preschool and later in school.

In its broadest meaning parental engagement involves partnerships between family, school and community, raising parental awareness about the benefits of being engaged in child's learning process, however, there are two commonly used terms describing the type of partnership between family and teacher: involvement and engagement. In preschool, involvement comes up as first sign of parental initiative to take part in the learning process. The term parental involvement, in contrast to engagement, refers only to those activities that take place in preschool such as volunteering, meeting with teachers and other preschool personnel, attending preschool events and other activities not directly related to learning process (Hill and Taylor, 2004).

Actual meaning of both terms slightly depends on the teacher's communicating and planning skills as well as overall level of partnership between all parties involved in learning process. The aim of this article is to reveal how to turn the initiative to involve in preschool learning process expressed by family, into planned engagement in learning process, and to foster 
children's learning skills and self-directed learning in preschool from theoretical and practical point.

Question of research: How to turn the initiative to involve in preschool learning process expressed by family, into planned engagement in learning process?

\section{Methods of research:}

1. Analyses of literature.

2. Empirical research methods: pedagogical observation, creative exercises and modeling, parent questionnaire, discussion.

Research sample consists of 24 children aged 6 to 7 years from the educational institution in Riga and 49 parents.

\section{Theoretical background of parental involvement and engagement}

The term parental engagement is the subject of much discussion and debate by researchers, and often used interchangeably with parental involvement and even parental participation (Weiss, 2009; Desforges \& Abouchaar, 2003). Some authors provide clear distinction between engagement and other forms of involvement, however the definitions used and the way these relate to attitudes and behaviour are not consistent.

Epstein's framework of six basic types on parental involvement (Epstein, 2002) provides a structure for parental partnership activities. In this model, term involvement incorporates certain activities that would be characterised as engagement.

\section{Table 1 Epstein's six types of involvement: keys to successful partnerships}

(Epstein, 2002)

\begin{tabular}{|l|l|}
\hline Parenting & $\begin{array}{l}\text { Assist families with parenting skills and setting home conditions } \\
\text { to support children as students (learners). }\end{array}$ \\
\hline Learning at home & $\begin{array}{l}\text { Involve families with their children on homework and other } \\
\text { curriculum-related activities and decisions. }\end{array}$ \\
\hline Communicating & $\begin{array}{l}\text { Conduct effective communications about learning programs and } \\
\text { child's progress }\end{array}$ \\
\hline Volunteering & $\begin{array}{l}\text { Organize volunteers and audiences to support the preschool and } \\
\text { children. Provide volunteer opportunities in various locations and } \\
\text { at various times. }\end{array}$ \\
\hline Decision-making & $\begin{array}{l}\text { Include families as participants in preschool decisions, and } \\
\text { develop parent leaders and representatives. }\end{array}$ \\
\hline $\begin{array}{l}\text { Collaborating with } \\
\text { the community }\end{array}$ & $\begin{array}{l}\text { Coordinate resources and services from the community for } \\
\text { families, children, and the preschool, and provide services to the } \\
\text { community. }\end{array}$ \\
\hline
\end{tabular}


Communicating, volunteering, decision-making and collaborating with the community relates to important socialising activities, but there are no sign of direct impact on learning outcomes. These are involvement type of activities. To support engagement in learning process we should look closer at parenting and learning at home, that fosters child's initiative and learning skills.

There is no doubt that the home environment and parent-child interactions have significant influence on child development from a very early age. On one hand, parental influence is an excellent tool for teachers, providing ability to extend the preschool activities to family by cooperating with parents, but on the other hand teachers has to establish trustful partnership with parents to reach this level of cooperation.

Trust between parents and teachers is vital if parents are to become appropriately and sufficiently engaged in their children's learning. Accordingly, positive and proactive relationships between parents and teachers are prerequisites for sustained participation in engagement initiatives (Bull, Brooking and Campbell, 2008). While relationships that are mutually reinforcing, respectful and directed toward improving a child's learning are integral to the success of engagement initiatives, they can be difficult and slow to establish (Kendall, 2008). If teachers are able to secure the trust of parents, then parents are more likely to respond to invitations to be involved in learning activities outside the preschool as well as activities that contribute towards their children's learning outcomes. This in turn reinforces parents' own sense of their role as educators (Hoover-Dempsey, 2005). Some parents have always been actively involved in enhancing their children's development and educational progress. This spontaneous activity of many parents has been seen as a valuable contribution to children's educational progress and attempts to enhance the involvement of all parents are now widespread. As majority of parents has very limited experience on partnerships with teachers and some of them has no idea on what to do, this is a role of teacher to plan and to manage relations with parents.

There are some common barriers, which need to be overcome in order to foster a sense of confidence in parents in their continuing role as educators across their child's learning path. For example, parents may not believe that their actions make a difference to their child's educational outcomes (Duckworth, 2009).

Bearing this in mind, it is important for teachers and other 'parent-facing' staff to consistently communicate to parents the importance of daily discussions about what their children are learning and their own expectations for them.

Most parents talk to teachers to some degree about their child's progress and this, quite properly is an index of parental involvement. It reminds us that the relationship between parental involvement and children's achievement is 
probably not linear (doubling parental involvement will not double achievement), and that it is proactive as well as reactive. Parents take the level of interest and involvement appropriate to the scene as they see it (Desforges \& Abouchaar, 2003).

\section{The empirical study of parental engagement in promoting children's learning skills}

The empirical part consist of planned activity together with children and their parents. A study carried out in one of Riga's preschool educational institutions using the projective game „New friend” whose main goal was to promote parental engagement and to encourage children to participate actively and to be creative in doing specific tasks together with 24 children and 47 parents.

To understand children's readiness for the planned activity, before projective game „New friend” started, it was performed an individual discussion with each child, and results was fixed according to the set of criteria (statements) regarding the initiative:

I like when other people organise games.

I like when I organise games.

I like to start new activities.

I like to learn new information.

Statements are pointing to a child's activity, and willingness to cooperate, to participate, as well as interest in the environment. Based on the answers teacher tried to estimate the percentage of expressed eagerness according to each statement.

Total group score averages according to the above criteria and based on the responses of children indicate children's desire results shown in table 2. Majority of children are willing to learn new information, which can be considered as evidence natural initiative for learning.

Table 2 Indication of expressed children's desire for activities

\begin{tabular}{|l|l|}
\hline Desire to learn new information & $95 \%$ \\
\hline Desire for new activities & $93 \%$ \\
\hline Desire to play when other people organize activities & $83 \%$ \\
\hline
\end{tabular}

While proposing different types of children's activities, parents had to record the reactions of children in specially prepared observation sheets, for example, one of the planned activities together with children is to make a toy, which will be given a name afterwards, and celebrated its birthday as well. 
Parents made notes based on their observations both free form, or based on certain criteria:

Was it necessary to encourage my child?

Did my child engaged in the process enthusiastically?

Dis my child involved others into the process?

Was this exercise interesting for my child?

Was this exercise interesting for myself?

Every day parents received the next day's exercise and recommendations from the teacher containing start-up ideas and possible children's issues, as well as the general recommendations of the successful progress of the game. For example, the topic ,first dinner with new friend" followed by recommended introduction for the activity. How your friend feels today, on what are on the dinner this evening? What could we cook together today? Who will read the recipe and who will cook?

After the first week, summarizing the earlier observation diaries obtained the following results: the first 2 days, 20 of the 25 children eagerly participated in the process involving family too, but starting from third day, activity declined stating that the child's interest and the interest of parents in exercise content is decreased. Until the end of the first week, 15 families took all exercises. Some parents tried to explain the reasons of not continuing the game as follows:

„Could not involve my child”, ,child was tired”, ,this activity did not seem interesting to my child”, "I'm not excited on these exercises, originally looked at with scepticism, now my child think the same", as well as phrases that pointed to an interest to continue the promotion of the child's initiative, using the projective game „New friend" in the framework of exercises:

„My child's activity was a surprise,” ,child is excited about the new game and discusses his skills, talents," „exercises prompted me to talk with child about things that otherwise may not do", ,the child's responses and thought process was a positive surprise."

Looking at the above feedback from parents and comparing them with their children, the answers given are able to explain the overall treatment to the exercises. For example, under the statement „I like it when the game is organised by another, girl replies that she does not like it. When looking at the questionnaire that mother filled out, there is a clear signs that the child does not like when mother organizes the game, and after the third day of a game interest is lost at all. All three mentioned questionnaires from parents indicate that the child had a significant impact from parents on their decisions regarding the exercises.

Comparing responses from boy with the parent's entries in the diary is a noticeable need for incentives that match the child's statement of „I like it when other people organise the games". 
Boy's parents refused to participate in the activities. According to the observation made by the mother, it was concluded that the child was not interested in the process. The mother's position is contrary to the child's answers that points to a great interest in learning new information, as well as loved when the others organizes the game. This example shows how strongly parent's attitude can influence the child's perception.

While discussing the progress of the game with the parents at the end of the first week, the parents found out that children are playing with the self-made toy much more that with old ones, bought in stores. Activating „New friend" theme in-group has generated many positive emotions and stimulated new ideas for children games both at home and in pre-school. Total interest over the learning activities has significantly grown (Vanaga, 2014).

Compiling notes and information from parents, in most cases fathers and mothers have similar vision on the process, as well as based on the notes it is possible to judge on the process of making „new friend" when the children involved the entire family.

In the first days of game „New friend” the children's activity and interest in the group was not noticeable, as well as conversations between the children of the "new friend" was not much. Teacher prompted to speak about "friends" game, encouraged children to make creative works together to bring them home to display to ,friend". Activity increased a lot. In the evening the kids went home and told parents that this work (Kaleidoscope, masks, drawings) should have be shown to „friend", as well as everything was discussed together with the parents, who are part of the everyday task. Even more activities and own written stories first appeared at the end of the week, when the group discovered the secret of the teacher, who also has a new "friend" to show.

\section{Conclusion and discussion}

To establish trustful partnership with parents, teacher should start from discussion face to face, clear explanation of planned activities, and showing expected results, so parents can easily understand the point of activities and expected benefits.

Activities planned and conducted by teacher creates lots of feedback from all involved parents and children. Started by a simple game, partnership strengthened week by week, and parents stopped asking for detailed explanations for what reason are all these tasks organised. Parent's curiosity replaced by confidence in teacher's suggestions and overall activity plan. The results of parental feedback shows progress in parenting skills and children's passion while telling about working together at home gives signs of good cooperation. 


\section{References}

Bull, A., Brooking, K., \& Campbell, R. (2008). Successful home-school partnerships. Report prepared for Ministry of Education by New Zealand Council for Educational Research. Retrieved from: http://www.educationcounts.govt.nz/publications/schooling/28415/3

Desforges, C., \& Abouchaar, A. (2003). The impact of parental involvement, parental support and family education on pupil achievements and adjustment: A literature review. Research Report 433. London: Dept. for Education and Skills. Retrieved from: http://www.bgfl.org/bgfl/custom/files_uploaded/uploaded_resources/18617/Desforges.p df

Duckworth, K, Akerman, R., Morrison Gutman, L., \& Vorhaus, J. (2009), Influences and leverages on low levels of attainment: a review of literature and policy initiatives. Institute of Education, University of London. Retrieved from: http://www.learningbenefits.net/Publications/ResRepIntros/ResRep31intro.htm,

Epstein, J. (2002). Six types of involvement: keys to successful partnerships. National Network of Partnership Schools, John Hopkins University, Baltimore.

Retrieved from: http://www.csos.jhu.edu/P2000/nnps_model/school/sixtypes.htm

Hoover-Dempsey, K. V., Walker, J. M. T., Sandler, H. M., Whetsel, D., Green, C. L., Wilkins, A. S., \& Closson, K. (2005). Why do parents become involved? Research findings and implications. The Elementary School Journal, 106(2), 105-130.

Retrieved from: http://www.vanderbilt.edu/peabody/family-school/papers/HooverDempsey2005.pdf.

Kendall, S., Straw, S., Jones, M., Springate, I., \& Grayson, H. (2008). Narrowing the gap in outcomes for vulnerable groups: A review of the research evidence. National Foundation for Education Research (NFER). Retrieved from: http://www.nfer.ac.uk/ nfer/publications/LNG01/LNG01.pdf

Vanaga, A., \& Rutka, L. (2014), Promoting of self-directed learning in cooperation with the parents for children in the preschool age. Society, Integration, Education. Proceedings of the Internationl Scientific Conference, Rēzekne: Rēzeknes Augstskola, 2014., ISSN $1691-5887$

Westmoreland, H., Rosenberg, H., Lopez, E., \& Weiss, H. (2009). Seeing is believing: Promising practices for how school districts promote family engagement. Issue Brief, Harvard Family Research Project \& National PTA.

Retrieved from: www.hfrp.org/content/download/3420/98238/.../SeeingIsBelieving.pdf 